\title{
ANALYSIS OF PERFORMANCE EVALUATION MODEL THROUGH THE BALANCED SCORECARD IN A FOOTWEAR INDUSTRY
}

Leonardo Perazza Universidade do Sagrado Coração (USC) - Brazil

E-mail:nicolle.panzuto@hotmail.com

MSe. Paulo César Chagas Rodrigues UNESP - Univ. Estadual Paulista - Brazil

E-mail: pauloccr@feb.unesp.br

Submission: $15 / 08 / 2010$

Accept: $30 / 09 / 2010$

\begin{abstract}
:
In recent decades, significant changes have been noted in the business world, due to the increasing demand of customers, political and economic moments that create a dynamic nonmarket increasingly unstable, contributing to increasing challenges in understanding the demands. The objective was to evaluate the model operations management method $\mathrm{BSC}$, in order to reduce costs and increase productivity and competitiveness. A study was conducted through a semi-open process, with 180 employees at a midsize company in the footwear industry Jaú, collecting information and data from the managers of each area. We conclude that the requirements for improved performance within organizations have made approaches for the management of operations evolve, becoming a broad and network management in the business, contributing to improvements in the condition of growth and sustainability of organizational activity. It is noteworthy, then, the need to use all available resources, minimizing problems and maximizing opportunities.
\end{abstract}

\section{INTRODUCTION}

The business environment, particularly in the footwear industry Jaú, has spent the last decades, for significant changes, they increase the competitive level of demand from customers, at times political and economic world and the dynamic nonmarket increasingly unstable, creating for companies increasing challenges in understanding the demands.

With the entry of Chinese products in Brazil, the quality of domestic products had to undergo a new adaptation, since the products using imported raw materials and labor force cheaper and, therefore, the level of dubious quality.

In order to compete on price level with the Chinese, the footwear industry Jaú started to develop products of high benefit, thus expanding its production to meet the higher social classes.

In order to maximize operational processes, we used the analysis of operations management balanced scorecard method, which helped identify the elements necessary to reduce costs by improving processes. 
From this context, the model management operations are being adapted by firms considered pioneers as a way to fit the new political and economic world, becoming a focus of academic study and implementation by other companies.

Starting from these premises were to study the mutual influence of the demand management and production systems, with the main focus of this work, introducing the key elements of each of these processes and their interactions: (a) As operations management influence the production system without having to generate new costs? (b) As the cost of imported goods bearing the footwear industry Jaú? (c) As the method Balanced Scorecard (BSC) can help to maximize their operations?

The aim of this study is to analyze the operations management performance by the method of Balanced Scorecard, a company in the footwear sector in the city of Jaú, in order to identify key characteristics that may affect the cost of productivity and competitiveness.

This research was restricted to analysis of the influence of operations management in a midsize company in the productive sector (footwear industry) and also in relation to geographical focus (the city of Jaú in the central-west of São Paulo). We used a literature review of the literature, research methodology to model a semi-open, and also the case study.

A scientific paper should include references, a review of literature to support the work of research and exploratory research and search and collection of information is systematic, for methodological work, or unsystematic, which does not provide clear and specific targets. (SANTOS; ROSSI; JARDILINO, 2000).

The following study used a methodology of quantitative and qualitative second Mioto Lima (2007), it is imperative to follow paths not random, because such research requires a high degree of critical vigilance of observation and careful selection and routing the methodological procedures.

We also used the case study, which to Yin (2005) case study is a case study that investigates a current phenomenon within its real context in which the boundaries between phenomenon and context are not clearly defined. According to this author, should be used multiple sources of evidence (A semi-structured, in-situ observation and analysis of documents) as evidence arising.

\section{MANAGEMENT OPERATIONS}

According Cavenaghi (2001), the requirements for improved performance within organizations for goods and services have made the approaches to operations management evolved over the years, becoming a broad and network management in the business, for an overview of the company as a whole, thereby contributing to improvements in the condition of growth and sustainability of organizational activity.

The concept of operations, addressing the process, according to Evans (1997), is a sequence of activities that produced a physical good, service or information to the consumer. Transforming customer needs for improvements in products hitting the high degree of satisfaction, seek new information technology to improve productivity and processes while avoiding waste, develop skills, adapt, and motivate employees through human resources practices.

According to Johnston and Clark (2002) and Rodrigues and Oliveira (2009b), operations management also involves the management of processes, people and resources to provide quality goods and low cost. According to these same authors, the operations manager must develop strategies for future operations to compete and / or 
follow into the future, find ways to motivate people in order to increase productivity without changing the quality of service, managing the daily operations performance required.

Corrêa and Corrêa (2005) and Rodrigues and Oliveira (2009a), argue that operations management handles the strategic activity of scarce resources (human, technological, informational, and others), the processes that deliver goods and services, meeting the needs of quality, time and cost to its customers and match these goals with efficient use of resources that the organization requires. These authors propose to treat the management of operations under the following aspects: (a) Addressing the strategic management of operations as a whole; (b) Addressing management operations as a "value package" for the client (physical goods and services); and (c) Understanding that the management of operations belongs to a network of operations that interacts with the system that serves the End User, ensuring that it is well served by encouraging their choice.

For Cavenaghi (2001) and Rodrigues and Oliveira (2008) then, Operations Management is the planning and ongoing control of people and resources, which involves decisions at all levels, to meet the needs of the End User.

\section{The System Performance Measurement}

According to Neely et al. (1995), a system of performance measurement should include measures individual inter-related, belonging to a particular environment, as shown in Illustration 1. When doing this project, one must question: (a) What performance measures will be used? (b) For they be used? (c) How much will they cost? (d) What benefits will provide?

To Lebas (1995), performance management is an organizational philosophy, supported by performance measurement. There is an interactive process between the two issues. The approaches are different, however, performance management is concerned with issues such as training, incentives, communication, as performance measurement, assesses the potential, entries, results and variances.

Bitici, Carrie and McDevitt (1997) consider that the system of performance measurement is the central information system of the process of performance management, where the organization manages its strategic and operational performance, in order to promote a proactive system of control still business, activities, tasks and people, and feedback is obtained through the measurement system performance by allowing an appropriate management decisions.

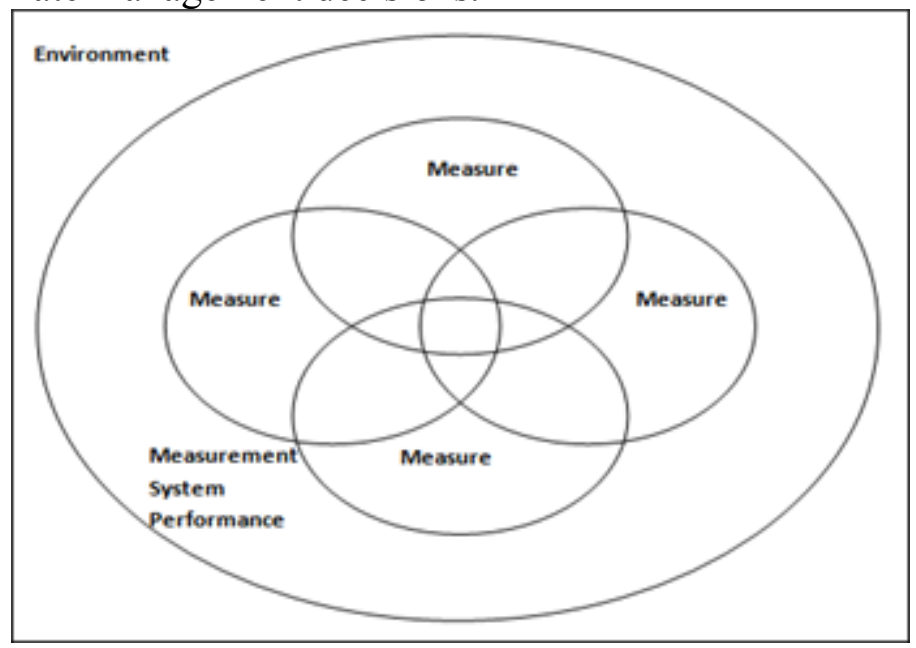


Illustration 1: A framework for the design of measurement system performance Source: Neely et al, 1995

For Martin (1998), the process of performance management is a means used for the organization to manage its performance, along with corporate and functional strategies and objectives. The competitive environment demands innovative products in technology and short life cycle, and therefore performance management is aligned to concepts: (a) Recognition of manufacturing as a source of competitive advantage; (b) Total Quality Management products and processes; (c) Company dedicated to the satisfaction of its stakeholders; (d) Competitive priorities: quality, cost, reliability, time, flexibility, innovation and service; (e) Integration of supply chain company, both internally and externally; and (f) Appreciation of teamwork and decision-making proactive.

According to Martins (1998), the system of performance measurement is the center of the process of performance management that integrates all of the systems development and review of strategy, management accounting, management by objectives, performance measures, non-financial structure of incentives and bonus for individual performance.

Martins (1998) lists the characteristics of new systems of performance measurement: (a) Equivalence with the competitive strategy; (b) Drive for continuous improvement; (c) Identify progress; (d) Be intelligible to the employees; (e) Cover the whole process of supply chain; (f) Information in real time; and (g) Evaluate the group and influence the attitude of employees.

According to Corrêa and Corrêa (2005), systems of performance measurement is the cycle of planning and control, essential for the management of operations, therefore, provide information about the performance that after evaluated, support the process of decision-making.

According to Corrêa and Corrêa (2005, p. 100), the establishment of an adequate system of performance evaluation is also important in influencing desired behaviors in people and systems operations for certain strategic intentions are more likely to actually become actions aligned with the intended strategy.

\section{BALANCED SCORECARD}

According to Kaplan and Norton (2001), the BSC transmits the mission and strategy held in different perspectives: financial, customer, internal business processes and learning and growth. Namely, the financial perspective is the guiding of the other, reported by strategy maps.

Niven (2002) defines the Balanced Scorecard (BSC) as a set of measures derived from the organization's strategy, a model for leaders to use in communicating with employees, customers and suppliers about the results for which will achieve its mission. As the BSC a system of measures, a strategic management system and a communication tool.

According to Johnston and Clark (2002), the BSC is a model best known for encouraging managers at all levels to invest in a more balanced set of measures. "The Balanced Scorecard to focus on specific measures selected to represent the organization's strategy" (Kaplan, 2005, p.42).

For Marchesan, Miorando and Caten (2006), the BSC seeks a solution to conflicts between the goals of short-and long-term strategic system. Thus, the goals represent its mission, as the basis of the indicator system. 
According to Kaplan and Norton (2001), each organization achieves its alignment and strategic focus in different ways, places and sequences, using the five principles, described in Illustration 2.

Also according to Kaplan and Norton (2001), organizations are in numerous sectors, business units and departments that have their own knowledge and culture. According to these authors, these divisions are the main barriers to implementation of the strategy, because there is great difficulty in communication and coordination between them. The organizational performance should be more than the sum of the parts and the individual strategies must be linked.

For Kaplan and Norton (2001), all employees must understand the strategy and lead the day-to-day processes, contributing to the success of its implementation. Executives can begin this process by using the BSC to communicate and educate the organization in the strategy to be implemented.

According to these authors, the strategy must be carried out through a double process continuous. Organizations introduce a process to manage strategy, integrating the management tactics with management strategies, using three processes: link strategy to budgeting processes, the process of reviewing the strategy and learning and adaptation strategy.

For Kaplan and Norton (2001), are the following key strategic themes: (a) Revenue growth and mix: refers to the expansion of products and services, offering options of higher added value and changing its pricing strategy; (b) Reducing the cost / productivity improvement, which refers to efforts to reduce direct costs and products and services and optimize the use of resources; and (c) Asset utilization / investment strategy: attention to the reduction of capital employed for growth, reallocate resources and exempt assets without adequate returns.

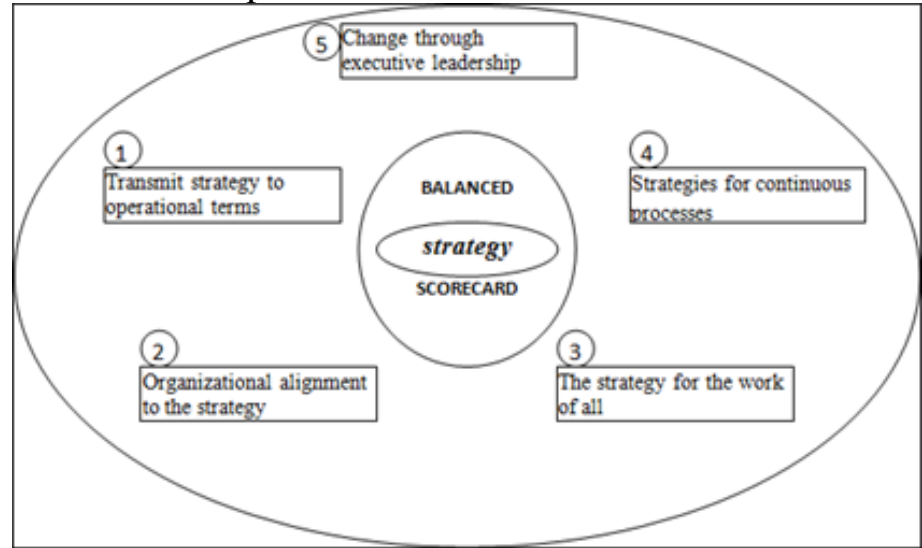

Illustration 2: The principles of organization focused on strategy

Source: Adapted from Kaplan and Norton (2001)

For Mendes (2002), goals and financial measures in a double role in setting the desired performance of the strategy, serving as a target for the goals and measures for all other perspectives of BSC. The Illustration 3 lists the financial goals with the other perspectives. 


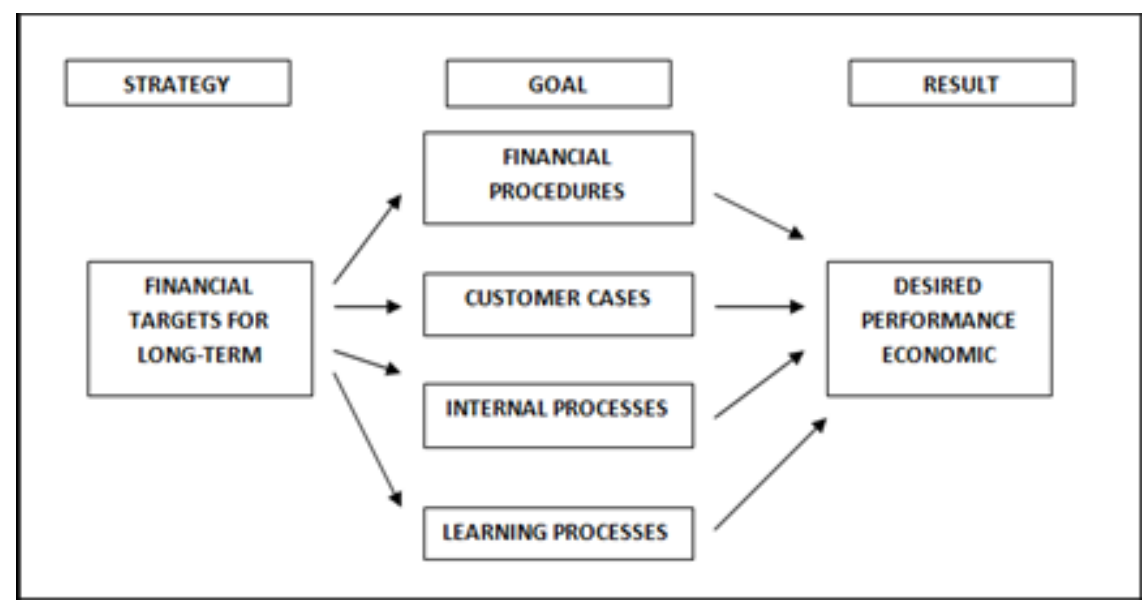

Illustration 3: Objectives and performance long-term economic Source: Adapted from Kaplan and Norton (1997)

According to Kaplan and Norton (2001), in the customer perspective of BSC, the focus should identify where the business units will compete and measures the performance of these targeted segments. The main outcome measures are: (a) Satisfaction, retention and customer acquisition; (b) Customer profitability; (c) Marketshare of the targeted segments; (d) Time and reliability in service; (e) Flexibility to create new demands; and (f) Development of new services.

Although the client perspective, Kaplan and Norton (2001) discuss the concept of offering value to customers, which represents the attributes that they can offer to build loyalty and customer satisfaction such as functionality, quality, price and time, requiring focus on critical internal operations to meet the needs of customers and about the prospect of internal business processes is to identify critical processes, the organization must achieve excellence, enabling business units meet the offering of securities that will win customers and meet the expectations of investors in financial return.

Kaplan and Norton (2001) show a model that companies can customize their internal process perspective, identifying customer needs and meeting them on three main perspectives: (a) Innovation process: identify the market and create the product / service; (b) Process operations: building and supports the products / services; and (c) After-sales: customer service.

According to Niven (2002), it is necessary to identify the key internal processes that will provide excellence in order to continue adding value for customers and shareholders.

The prospect of learning and growth, according to Kaplan and Norton (2001), to identify the infrastructure that the organization must build to create long-term growth to improving their skills to improve quality and adding value to customers and shareholders. She comes from three sources: (a) eople; (b) Systems; and (c) Organizational procedures.

From the perspective of learning and growth, Kaplan (2005), the focus of measurement would be related to the goals as satisfaction, retention and employee productivity.

To Niven (2002), the prospect of learning and growth is the basis for other perspectives, as it covers the ability of developers and information systems that are the basis for achieving the results you require other perspectives. 
Kaplan and Norton (1996) argue that the BSC transmits the vision and strategy through a set of perspectives, including measures of expected outcomes and processes will drive for future results. For these authors, the four perspectives are most important to demonstrate the organization's results, however, there is the possibility of adding one or more perspectives, since other parties may be important in the business strategy.

According to Kaplan and Norton (1996), there are two important indicators in the CSD: the outcome indicators (lagging indicators) that show past performance and the effects of decisions, and leading indicators (leading indicators) that show what should be carried out to obtain long-term results.

Kaplan (2005) associates the BSC model to the model McKinsey 7-S, which provides seven factors critical to the implementation of the strategy: (a) Strategy; (b) Structure; (c) Systems; (d) People; (e) Skills; (f) Cultural Organization; (g) Shared values.

According to the analysis of Kaplan (2005), both models have a synergy, they require a multidimensional approach. They have a relationship of cause and effect and help managers direct their organizations to effectively implement the strategy.

Kaplan (2005) concludes that the BSC can also help implement the use of the McKinsey 7-S, broadcasting the seven factors of the model by means of measurable goals that will lead to action and feedback.

Attadia, Canavarolo and Martins (2003) believe that the successful implementation of the BSC depends on factors such as conceptual little-explored factors related to vision, entrepreneurship, the game of power, influence of culture and leadership. According to these authors, other criticisms are related to structural failures relating to the configuration of the $\mathrm{BSC}$ as a lack of detail in the development of performance measures, lack of detail in data collection and lack of insight into the actions of competitors.

Finally, the authors cite the reviews as managerial failures of management in implementing the BSC: translating the vision, communication and networking strategy, business planning and feedback and learning.

Voepel, Leibold and Eckhoff (2006) Critics of the Balanced Scorecard model saying that the model has a static structure that forces the existence of only four prospects and therefore does not adapt to changes in the new economy and that, being a routine processes, does not stimulate the creativity of employees.

Responding to these criticisms, Kaplan and Norton (2006) argue that in the chapter "Four Perspectives: Are these sufficient?" Was envisaged that some organizations may use more of other perspectives, according to its merits and according to these authors, firms may using the BSC model to adapt their strategies, gaining knowledge and economic conditions, generating new ideas from the organization.

Finishing the criticism, Voepel, Leibold and Eckhoff (2006) argue that the BSC has a mechanistic and linear thinking difficult performance in modern business, where networks and interconnections are increasingly present. They suggest that companies rethink their creations with their own system of measurement.

Kaplan and Norton (2006) counter that the authors violate the principles of the academy, they encourage organizations to replace a model tested and proven around the world for a model without reference publications that claim to have been successful only in an organization .

Pietro et al. (2006), says a survey conducted in the field, that $93 \%$ of the factors for the failure of the implementation of the Balanced Scorecard is the lack of 
commitment from top management. According to these authors, other critical situations highlighted the discussions are not clear and infrequent, not using the BSC as a continuous process and not the division of responsibilities.

Although the Balanced Scorecard has been used in large enterprises around the world, the climate and other ideas and models have been placed on academic and scientific. Voepel, Leibold and Eckhoff (2006) suggest the abandonment of the companies, however, the set temperature can be used constructively in order to provide improvements in applications along with other existing models or on the rise.

\section{CASE STUDY}

The case study was carried out in a footwear company Jaú, through data collection, which was based on a standard questionnaire with semi-open. The purpose of this model questionnaire is able to collect information and data with key managers of each area of the company.

The history of footwear Jaú began in the nineteenth century with the arrival of an Italian who installed the first shoe store in town. At this time, there were a handful of leather and footwear were made on a full scale. In 1943, the historical data was based industry first legally constituted and, shortly thereafter, there were many others, established by those who were employees.

Footwear manufacturers have begun to gain some political projection, having elected, years later, Mr. Jarbas Farracco, Mayor of Jaú, 1968 to 1972. The industries have evolved and the work initially craft, have been carried out with the aid of high-tech machines.

In 1979 he founded the Association of Footwear Industries of Jaú, to defend the interests and represent the business sector. Since then, the number of companies grew, and today, Jaú is known as the Shoe Capital Male. It is estimated that there are about 250 industries, responsible for generating over 16 thousand direct and indirect. The footwear sector now accounts for more than $40 \%$ of the GDP of the city, being a major contributor to the economic and industrial development.

The city of Jaú houses a concentration of industries of women's shoes with $90 \%$ specializing in products made of leather, as well as companies that supply chain, educational institutions, technical support and financial and other companies that feature a Local Productive Arrangement (APL). The APL consists of approximately 1182 formal establishments, in which 250 companies are women's shoes, 800 newsstands Service, 120 companies of shoe components, leather, companies of leather and 3 malls with 175 stores shoes.

Together these companies generate about 17 thousand direct jobs, divided by 8390 at the Footwear Industry, 4000 on newsstands service providers; 1400 in parts companies, 80 in the tanning of Jaú, 100 enterprises and artifacts; 400 jobs in the malls.

The production of APL is approximately 130 thousand pairs per day, with capacity to increase production by $30 \%$. The footwear sector now accounts for more than $40 \%$ of the GDP of the city, being a major contributor to the economic and industrial development of the municipality.

The company submitted the study is characterized by a manufacturing industry of women's shoes of various types such as Mules, Scarpins, Chanel, Peep Toe, Shoes, Sandals, Boots, Strains, Anabelas and Slipper in Table 1 is shown percentage production of each model. It has approximately 120 direct employees (employed at the factory) and about 50 indirect employees (outsourced services), plus a few seasonal 
employees, which total approximately 180 employees. The company has a large share of activity in large networks (or magazines) and, moreover, also has representatives who work in Brazil, with a maximum coverage area is in the greater São Paulo and Rio de Janeiro.

Initially, the company was setting up family, with few employees, little machinery, reduced physical space and with little administrative structure. But with the development and growth were set general policies that caused it to cease the main features of a family business, which made today a very structured company.

The company currently has 10 types of shoes, which generate about 180 models, which can be produced without difficulty purchasing raw material, which is one of the main reasons that make a collection to be abolished to make way for a another, with new trends in materials and fashion.

Table 1: Types of models manufactured by Company A in each station

\begin{tabular}{|l|l|l|l|}
\hline Type & Qtd.Modelos & $\%$ & Season \\
\hline Sandals & 40 & $22 \%$ & Summer \\
\hline Creeper & 35 & $19 \%$ & Summer \\
\hline Peep Toe & 25 & $14 \%$ & Half-season \\
\hline Cepa & 12 & $7 \%$ & Half-season \\
\hline Anabela & 12 & $7 \%$ & Half-season \\
\hline Slipper & 12 & $7 \%$ & Half-season \\
\hline Scarpin & 15 & $8 \%$ & Winter \\
\hline Mule & 12 & $7 \%$ & Winter \\
\hline Chanel & 12 & $7 \%$ & Winter \\
\hline Bota & 5 & $3 \%$ & Winter \\
\hline TOTAL & $\mathbf{1 8 0}$ & & YEAR \\
\hline
\end{tabular}

The variation of modeling is determined by the seasons and the fashion trends. This makes the process very dynamic, especially in today's market, which is increasingly demanding as new products.

For the production of women's shoes, the stations are considered as follows: (a) Winter: it has a specific modeling for the climate, with more closed shoes; (b) Summer: also has its specific modeling, which is always easier to produce the shoes having a more open construction; and (c) Fall / Spring is considered half-season for production purposes, with semi-open shoes, that meet the temperature changes of this period and in the regions served.

The board is responsible for making important decisions, or that involve drastic or sudden changes in some of the business processes that may affect in the end items such as: Quality, Quantity Production, Value Billing, and each sector or department within the company has a manager or boss who is autonomous and is responsible for decision making smaller, day-to-day and affecting only a small part of a certain process thus not affecting the company in general.

There is a pre-defined production as the industry should reach its daily goal to keep the values of a stable cost for the company to not pass a loss with the loss of production, since fixed costs are linked and calculated directly as a function of total daily production. All this strategy is reviewed weekly by all managers and leaders of industries that come together to try to develop and implement strategies that can help better the difficulties of all sectors involved in the process. 
As the strategy of the production process, there is also a strategy to achieve competitive advantage. Very important in today's market where there is large supply of cheap goods coming mainly from other countries with China, for example, some measures are critical to achieve competitiveness as a good choice of suppliers of raw materials that have the agility and quality of delivery and competitive prices, to avoid wasting time and materials are mainly used properly of them, get good prices of raw materials by buying and planned large amount of forming partnerships with suppliers and even customers and also make a good balance of labor-cost labor (for some production processes) and labor-skilled (high quality) to ensure that this is actually done.

The company's mission is to always keep the focus on excellent service and quality products with competitive prices, to become an increasingly strong company with good partners in order to become a leader in the shoe industry and female fashion. Its main objective of operations strategy is to carry what is designed on paper to reality of a production, following all the steps in the pre-defined strategy.

The main indices used in the company as measures of process performance are: Production Quality and Quantity of Production. Each part of the company has a daily control of how much was produced in that process and the level of quality was obtained for this quantity. It is taken into account the number of defects found at the end of the process, the number of couples with poor workmanship and other minor factors.

In all sectors of production are made to measure performance: Modeling (Technical): there is a number of models prepared and how many of them have problems in the production process; Warehouse: there is the agility in the supply of production and that as this occurs, if there are missing parts or materials at the entrance of the item in production; Court: There is a quantity of cut and how any waste or use thereof, and stitching: there is a number of pairs sewn on and of those, what percentage of defects caused by poor quality in the process, and finally the assembly: there were many pairs of shoes were assembled at the end of the day and again the amount of material defect or wasted in the process by poor management materials.

This performance measurement has as main objective, to oversee all cases individually to see if everyone is reaching satisfactory levels of performance of each sector, because if you have any kind of problem of any kind, it can be detected easily and taken the necessary steps to that sector falls within the standard of the company without compromising the entire process of production. The organization manages its performance, together with corporate and functional strategies, and objectives, because everything is part of a single context closely related to each other. The company can never achieve the goals if the performance or strategies are failing, the strategy will never work if performance is bad, satisfactory performance will never occur if the strategy is wrong. All administration is always paying attention to these factors as a whole company.

For industry, a string of values representing the set of activities performed by the company from its dealings with suppliers and production cycles and selling to the phase distribution of the product. It's all action that is needed to transform raw material into final product is well made and that adds value not only money but also the intangibles such as product awareness.

You can identify the link between long-term strategies with short-term actions, for all short-term action that is performed, except that some are influenced by the drastic change of the economy, is an action aimed at improvement of the production process to 
achieve strategies and long-term goals. The company seeks to continually improving and refining the same way that the change strategies and objectives are achieved. These traces are new goals, and continues the cycle indefinitely and all this happens with short-term actions that at any given time will achieve the long-term strategies.

With the help of the growing industry of Information Technology, both in the area of software and products and the area of training courses, virtually all sectors of the company communicate through instant messaging software and e-mail. This causes the productive and administrative processes should be linked with greater efficacy and safety, since all sectors are getting all the information that is part of the process. For the functionality of the system has a communication management for a specific career, which guarantees the quality and safety standards.

The outlook for the financial processes are geared to capital growth and cash flow while maintaining the financial health of the company and achieve stability in the marketplace. For internal processes, the prospects are aimed at continuous improvement of production processes, seeking the overall quality of the final product, reducing gaps between processes, in addition to ongoing concern about the satisfaction of employees and waste production that will affect their environment. The growth and learning, the prospects for a steady flow of technological developments in machinery and computer equipment, training of skilled qualified workers within the company to the management of courses and technical information given to employees. In relation to the customer perspective, these aims the development of products that have a high level of acceptability and quality, and delivery days in what is proposed by them, trying to get a strong brand and market knowledge.

For this organization, the prospect of achieving excellence in product quality and the same quality production for all parties involved, from the making of the display, sales, processing, production, final product and customer is very important for the end customer, satisfied, can serve as marketing.

\section{CONCLUSIONS}

The theoretical framework was useful for the study, since it allowed a more critical view on the subject studied and the behavior of footwear companies that seek to maintain its production level, partnerships between suppliers and customers, in order to keep deadlines scheduled deliveries and the growth of its capital, different from that proposed by the authors of the bibliographies studied.

Through interaction with the company, we can see that but measurement of the performance of competitive dimensions such as cost, quality, speed, among others, were important, the resulting information would be of little value if they were not suited to organizational needs. Although the cost reduction be considered important, the company's main objective is to maintain quality in their manufacturing and production quantity.

The model analyzes the balanced scorecard performance management of the companies on four perspectives: financial, customers, processes and learning, these perspectives are not viewed clearly in the industry studied. The company is interested in cost reduction, from the moment that's going to rework some sections, the time of manufacture of shoes is beyond the preset limits on the strategy and the purchase of raw material costs are exceeding the originally calculated .

The management of operations, mainly using of the model can capture the value that the company does need to insert into their final product, or add attributes to shoes, 
the services provided customer service and image that the company is to customers. And for that, it is necessary to generate new costs, and yes, identify the real mission of the company, which is seen and followed by all levels (strategic, tactical and operational).

For the company studied, may also be noted that there is a pre-defined as the actions of short and long term, since the entry of imported products at extremely low costs, industry has innovated and created a "half-season "to make new products, thus leaving the normal pattern of industries in the same sector. This provides continuous changes in production, adapting to ever to market requirements.

Following the concepts of the BSC, the industry can maximize its operations without financial costs there are surplus, measuring the operating performance of each sector and directing one to a predetermined goals, so that every problem is easily detected and taken appropriate action to that sector falls within the pattern of the company without compromising the entire process of production.

Because of that, the shoe industry in question is not totally out of context studied, however, it is necessary to readjust some sectors through the implementation of the BSC in its strategic management to increase its competitiveness in the market, keeping ahead of new trends in management of operations.

\section{REFERENCES}

ATTADIA, L. C. L.; CANAVAROLO, M. E.; MARTINS; R. A. (2003) Balanced Scorecard: Uma análise crítica. In: ENCONTRO NACIONAL DE ENGENHARIA DE PRODUÇÃO, 23, 2003, Ouro Preto. Anais... Ouro Preto: ABEPRO.

CAVENAGHI, V. (2001) Gestão do desempenho empresarial: A contribuição da área de manufatura. Tese (Doutorado em Engenharia de Produção) Programa de Pós-Graduação em Engenharia de Produção, USP, São Paulo.

CORRÊA, H. L.; CORRÊA, C. A. (2005) Administração de Produção e Operações:

Manufatura e Serviços: uma abordagem estratégica. ed. compacta, São Paulo: Atlas.

EVANS, J. R. (1997) Production Operations Management: Quality, Performance and Value, 5th ed. St. Paul: West.

JOHNSTON, R.; CLARK, G. (2002) Administração de Operações e Serviço, São Paulo: Atlas.

KAPLAN, R. S.; NORTON, D. P. (2001) Transforming the balanced scorecard from performance measurement to strategic management: Part II. Accouting Horizons. v.15, n.2, p. 147-160.

KAPLAN, R. S.; NORTON, D. P. (2004) Mapas Estratégicos: convertendo ativos intangíveis em resultados tangíveis. Rio de Janeiro: Campus.

KAPLAN, R. S.; NORTON, D. P. (2006) Response to S. Voepel et al. "The tyranny of the Balanced Scorecard in the innovation economy". Journal of Intellectual Capital. v.7, n.3, p. 421-428.

KAPLAN, R. S. (2005) How the balanced scorecard complements the McKinsey 7-S model. Strategy \& Leadership. Chicago, v.33, n.3, p. 41-46.

LEBAS, M. J. (1995) Performance measurement and performance management. International Journal of Production Economics. v.41, p. 23-35. 
LIMA, T. C. S.; MIOTO, R. C. T. (2007) Procedimentos metodológicos na construção do conhecimento científico: a pesquisa bibliográfica. Revista Katál. Florianopolis, v. 10, n. esp., p. $37-45$.

MARCHESAN, C. H.; MIORANDO R. F.; CATEN, C. S. (2006), Building Competitive Advantage using Performance Evaluation. In: INTERNATIONAL CONFERENCE IN INDUSTRIAL ENGINEERING AND OPERATIONS MANAGEMENT, 12., 2006, Fortaleza. Proceedings... Rio de Janeiro: ABEPRO.

MARTINS, R. A. (1998) Sistemas de Medição de Desempenho: Um modelo para Estruturação do Uso. 1998. Tese (Doutorado em Engenharia de Produção) - Programa de PósGraduação em Engenharia de Produção, USP, São Paulo.

MENDES, D. P. (2002) O Balanced Scorecard como instrumento de avaliação do nível de desempenho logístico em uma empresa de prestação de serviços. 2002. Dissertação (Mestrado em Engenharia de Produção) - Programa de Pós- Graduação em Engenharia de Produção, UFSC, Florianópolis.

NIVEN, P. R. (2002) Balanced Scorecard step-by-step: Maximizing Performance and Maintaining Results, New York: John Wiley \& Sons, 2002.

NEELY, A.; GREGORY, M.; PLATTS, K. (1995) Performance measurement system design. International Journal of Operations Management. Cambridge, v.14, n.4, p. 81-114.

PRIETO, V. C.; PEREIRA, F. L. A.; CARVALHO, M. M. C.; LAURINDO, F. J. B. Fatores críticos na implementação do balanced scorecard. Gestão \& Produção. v.13, n.1, p. 81-92, 2006.

RODRIGUES, P. C. C.; OLIVEIRA, O. J. (2008) A study of management of intermediate inventory in the manufacture of paper products in Brazilian companies. In: PRODUCTION and OPERATION MANAGEMENT SOCIETY 2008, La Jolla. Proceedings... La Jolla: POMS, 1 CD-ROM.

RODRIGUES, P. C. C.; OLIVEIRA, O. J. (2009a) The importance of analysis of production system Engineering-To-Order and Make-To-Stock in two business sector graph In: INTERNATIONAL CONFERENCE IN INDUSTRIAL ENGINEERING AND OPERATIONS MANAGEMENT, 15., 2009, Salvador. Proceedings... Salvador: ABEPRO.

RODRIGUES, P. C. C.; OLIVEIRA, O. J. (2009b) Analysis of the Influence of Strategic Management of ETO Demand on Management of Stock in a Printing Industry In: PRODUCTION and OPERATION MANAGEMENT SOCIETY 2009, Orlando. Proceedings... Orlando: POMS.

SANTOS, G. T.; ROSSI, G.; JARDILINO, J. R. L. Orientações metodológicas para elaboração de trabalhos acadêmicos. 2 ed. São Paulo: Gion Editora, 2000.

VOEPEL, S. C.; LEIBOLD, M.; ECKHOFF, R. A. The tyranny of the Balanced Scorecard in the innovation economy. Journal of Intellectual Capital. v.7, p. 43-60, 2006.

YIN, R. K. Estudo de caso: planejamento e métodos. 3 ed. Porto Alegre: Bookman, 2005. 